\title{
可搬型 MMS「Pegasus：Two」の特徵と今後の可能性
}

高橋 義雄* ·阿部 亮吾* ・ 山口伸* - 小山田智紀*・川嶋 良純*・横尾 泰広*

\section{Pegasus : Two の概要}

可搬型 MMSである Pegasus：Two（Leica Geosystems 社製,「以下本システム」) は高密度三次元 点群デー夕を取得するレーザスキャナと, $360^{\circ}$ 全方位 画像を生成するための 7 台のカメラを搭載している。 これらのレーザスキャナとカメラは厳密にキャリブ レーションされていることから，図１に示す色付き点 群デー夕を容易に作成することができる。色付き点群 デー夕を参照することで, 容易に横断歩道や植栽など の地物を識別することができる。また，オプションと して路面性状調査用カメラ 1 台を搭載し, $5 \mathrm{~mm}$ 解像 度の路面オルソを作成することができる。本システム の最大の特徵は, カメラやレーザスキャナを一体化し

表 1 Pegasus: Two の仕様

\begin{tabular}{|c|c|c|}
\hline \multirow[t]{5}{*}{ システム構成 } & レーザスキャナ & 1 台 \\
\hline & カメラ & $7+1$ (下向き) 台 \\
\hline & GNSS & 最大 2 台 \\
\hline & IMU & 1台 \\
\hline & DMI（距離計） & 1台 \\
\hline \multirow{5}{*}{$\begin{array}{l}\text { レーザスキャナ } \\
(\mathrm{Z}+\mathrm{F} \\
\text { PROFILER } \\
9012)\end{array}$} & 回転数 & $200 \mathrm{~Hz}$ \\
\hline & \begin{tabular}{|l} 
相対精度 \\
(反射精度 $80 \% ， 50$ 以内)
\end{tabular} & $0.2 \mathrm{~mm} \sim 0.98 \mathrm{~mm}$ \\
\hline & 取得方式 & 位相差 \\
\hline & スキャン点数 & 最大 100 万点/秒 \\
\hline & 計測レンジ & $0.3 \mathrm{~m} \sim 119 \mathrm{~m}$ \\
\hline \multirow[t]{2}{*}{ カメラ } & 画素数 & 400万画素 \\
\hline & 下向きカメラ路面解像度 & $3 \sim 5 \mathrm{~mm}$ \\
\hline GNSS & $\begin{array}{l}\mathrm{L} \text { Lバンド, SBAS, QZSS } \\
\text { のトリプルバンドで受診 } \\
\text { 可能 }\end{array}$ & $\begin{array}{c}\text { GPS } \\
\text { GLONASS } \\
\text { Gallileo } \\
\text { BeiDou } \\
\end{array}$ \\
\hline IMU & 10秒停止後の位置精度 & $\begin{array}{l}\text { 水平方向：0.02m RMS } \\
\text { 鉛直方向：0.02m RMS } \\
\text { ピッチ/ロール }: 0.008^{\circ} \mathrm{RMS} \\
\text { ヘディング }: 0.013^{\circ} \mathrm{RMS} \\
\end{array}$ \\
\hline \multirow[t]{2}{*}{ DMI（距離計） } & 回転速度 & 1,000パルス/回 \\
\hline & 防水・防塵性能 & IP67 \\
\hline
\end{tabular}

*国際航業株式会社

「写真測量とリモートセンシング」VOL. 56, NO. 5, 2017
た上にバッテリ駆動により可搬とし，車だけでなく台 車，船舶，鉄道に搭載できる点である。本システムの 仕様を表 1 に，主な特徵を以下に示す。

・可搬型の特徵を活かし, 台車/船舶などに搭載するこ とで, 歩道, 自転車道, 護岸等で計測することがで きる。

- 画像撮影時の輝度, バランス自動コントロール機能 により，色調差の少ない全方位画像を作成すること ができる。

・車両の搭載に際して, 改造が不要である。

・最新の GNSSレシーバ搭載による高精度な測位が 可能である。

\section{Pegasus : Two データの特徵}

本システムを車両へ搭載し, 車速約 $50 \mathrm{~km}$ で自動計 測された色付き点群デー夕を図 1 に示す。スキャン点 数が最大 100 万点/秒という特徵を生かし, 点密度約 3,000 点 $/ \mathrm{m}^{2}$ という結果が得られた。

自転車専用トンネル (高さ：約 $2.8 \mathrm{~m}$, 幅：約 $2.7 \mathrm{~m}$ ) を台車で計測した結果を四 2 に，本システムを船舶へ 搭載して川の護岸を計測した結果を図 3 に示す。また, ブロック被覆の段差について，現地でメジャーを当て て計測した結果を図 4 に, 点群から計測した結果を困 5 に示す。いずれの計測結果も約 $86 \mathrm{~mm}$ であり, 精度 良く計測できたことから, 今後は施設等の変状調査で の Pegasus：Two の利用が期待できる。

\section{Pegasus：Two の今後の可能性}

本システムの最大の特徵である可搬性を活かし, 屋 内計測, 坑内計測での利活用やアセットマネジメント に資する基礎資料としての利活用を進めていきたい。 また, 計測レンジは従来型より短いが, 点密度が高く, 相対精度が高いという特徵から, 路面性状調査での利 活用も進めていく予定である。 


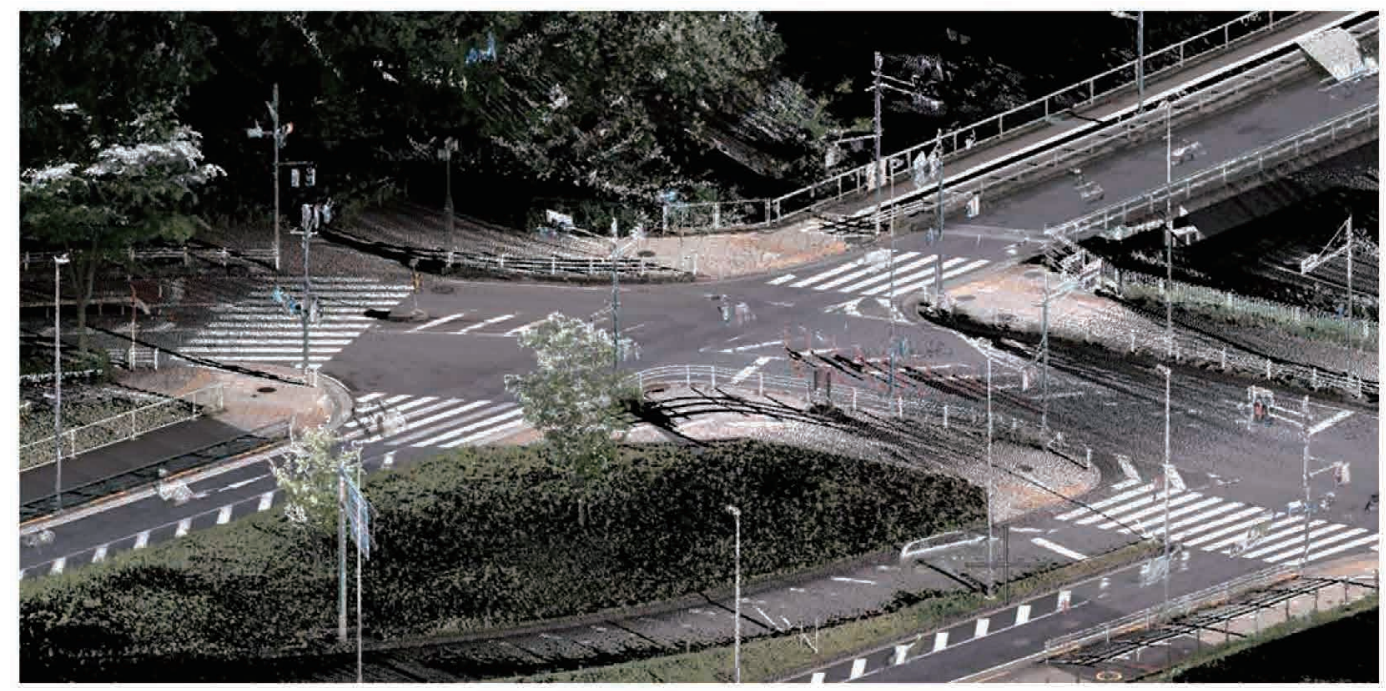

図 1 車載計測による色付き点群データの例
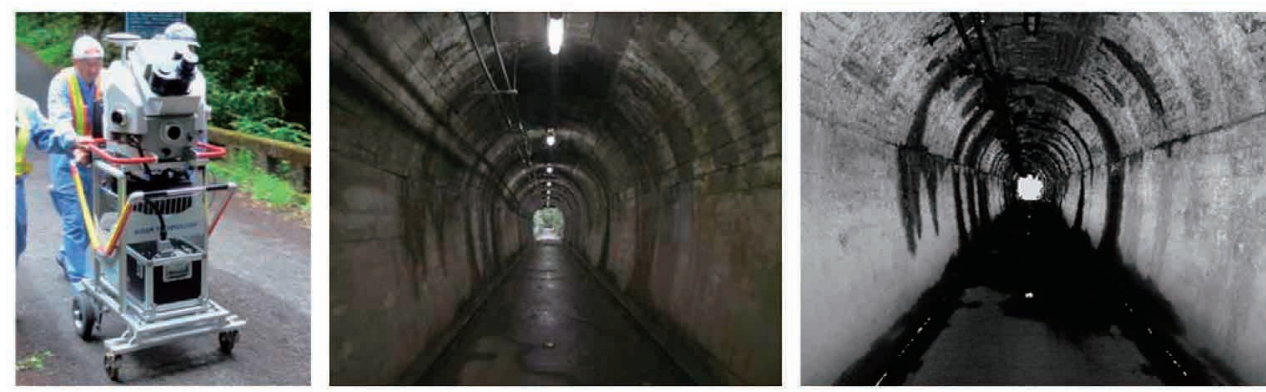

図 2 台車による自転車専用トンネルの計測（左：計測風景, 中央：カメラ画像, 右：反射強度点群）
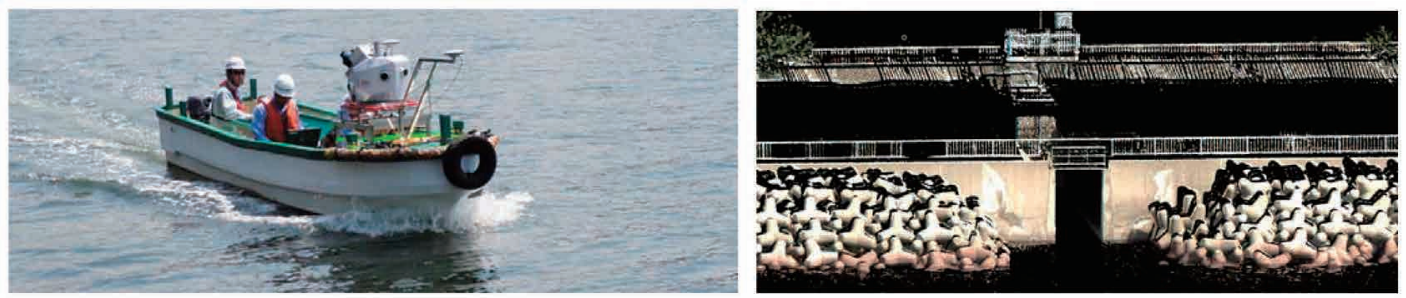

図 3 船舶による川の護岸の計測（左：計測風景, 右：色付き点群データ）

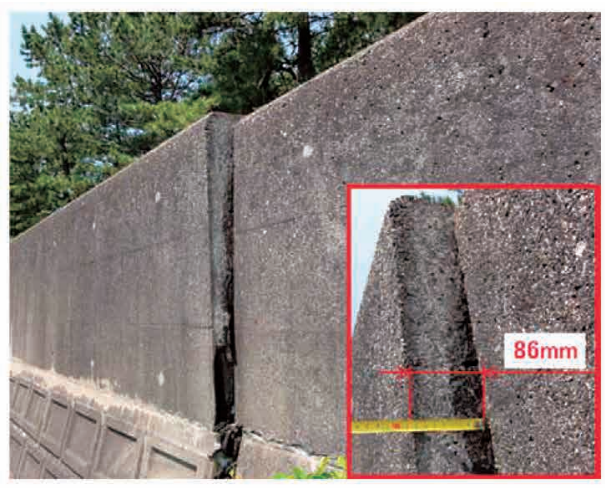

図4＼cjkstart写真撮影したブロック被覆の段差

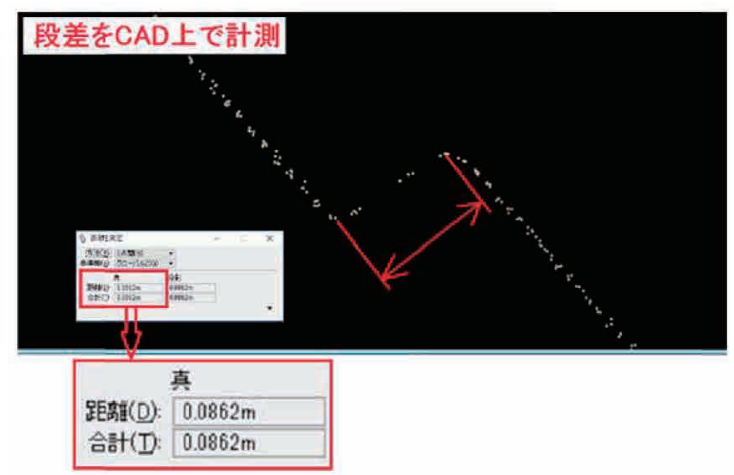

図 5 CAD 上で計測したブロック被覆の段差 